\title{
Breast cancer metastasis from Gastric Carcinoma in a young female
}

\author{
Sara Jamil Nidhamalddin ${ }^{1}$, Hemin Abdulwahab Hassan², Kalthum Ali ${ }^{3}$, Khalid Anwar Hama Ghareeb ${ }^{4}$, \\ Mohammed Ibrahim Mohialdeen Gubari ${ }^{5}$
}

\begin{abstract}
Gastric cancer is a disease of elderly patients and mainly metastasis to liver, lung, and peritoneum, while signet ring cell is a variant of gastric cancer and commonly metastasis to peritoneum and lymph nodes. Metastasis to mammary is a rare condition which account for $3 \%$ and has poor prognosis. Generally extra mammary carcinoma precedes breast metastasis by 2 years. It's uncommon to have breast metastasis as a first manifestation of extra mammary malignancies. There is no age limit and presentation my mimic primary breast cancer. Due to rarity of this condition there are no consensuses about clinical, radiological and histological features which make it a challenging task to distinguish primary from metastatic breast neoplasm. The case bellow is a young woman with diagnoses of diffuse-signet ring cell gastric cancer. First presentation was right breast edema with ascites, peritoneal nodules, and enlarged enhancing ovaries on imaging. Biopsy from each site confirmed involvement by metastatic adenocarcinoma with signet ring pattern. Her condition progressed after 5th cycle of EOX.
\end{abstract}

Keywords: Gastric cancer, breast metastasis, young age

\section{INTRODUCTION}

Gastric cancer at young ages is rare. The median age at diagnosis is 71 years and is the second most common cause of death worldwide (1).

Incidence of signet ring cell gastric cancer ranges from 3.4\% in Japan to 39\% in western countries $(2,3)$ and accounts for $29 \%$ of gastric cancers, it occurs most commonly in women and mainly younger age groups, it is less chemo-sensitive with poor prognosis than intestinal type $(4,5)$. Diffuse-signet ring cell type exhibits very little cell cohesion with predilection for extensive sub-mucosal spread and early metastasis (6), diffuse form's main carcinogenic event is loss of E-cadherin expression through mutation of $\mathrm{CDH} 1$ gen (7).

Carcinoma of stomach can spread by local extension, hematogenous spread, lymphatic dissemination or seeding of peritoneal surface, wide spread metastasis may involve any organ, especially liver, lung and peritoneum $(6,8,9)$, while signet ring cell subtype's main metastatic sites are peritoneum and lymph nodes rather than liver (10).

Metastatic lesions to the breast from extra-mammary neoplastic lesions are unusual with poor prognosis. The most common reported sources are malignant melanomas, lymphoma/leukemia group, contralateral breast carcinoma, lung carcinoma and carcinoid tumors $(11,12)$. There is no consensus on a distinct clinical and radiologic presentation $(12,13)$. Although diagnosis of primary malignancy usually precedes detection of the breast lesion in some cases may have no history of malignancy (13).

\footnotetext{
1 Medical Oncologist, Department of Medical Oncology, Hiwa Cancer Hospital, Sulaymaniyah, Kurdistan Region, Iraq.

2 Histopathologist, Department of Pathology Lab, Hiwa Cancer Hospital, Sulaymaniyah, Kurdistan Region, Iraq.

3 Radiologist, Department of Radiology, Hiwa Cancer Hospital, Sulaymaniyah, Kurdistan Region, Iraq.

$4 \mathrm{MSPH}, \mathrm{BPH}$, Research Department, General Directorate of Health, Sulaimani, Iraq.

5 PhD, MSC, HDCM, BPH, \& DCM, Department of family \& Community Medicine, Collage of Medicine, University of Sulaimani. Sulaimani, Iraq.
}

\author{
Correspondence: Sara Jamil Nidhamalddin \\ Medical Oncologist, Department of Medical Oncology, Hiwa Cancer Hospital, \\ Sulaymaniyah, Kurdistan Region, Iraq. \\ E-mail: sara.j.nidham@gmail.com
}

Received: 29 Jun 2019, Accepted: 25 Nov 2019

(C) 2019 by the authors; licensee Modestum Ltd., UK. This article is an open access article distributed under the terms and conditions of the Creative Commons Attribution License (http://creativecommons.org/licenses/by/4.0/). 

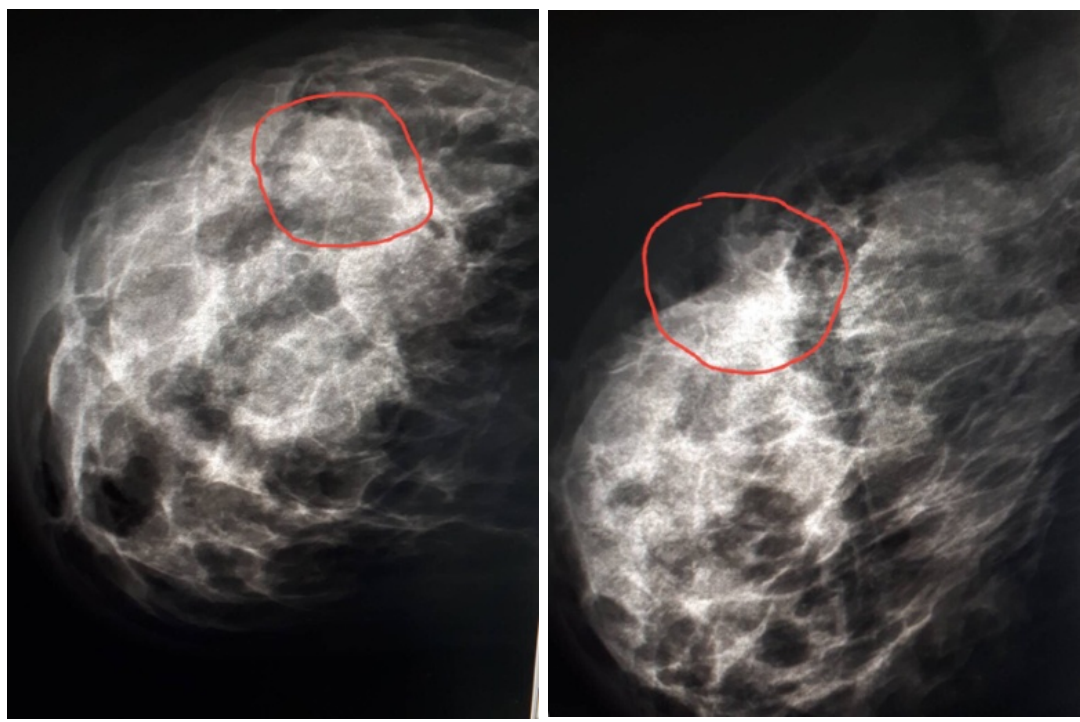

Figure 1: Mammography

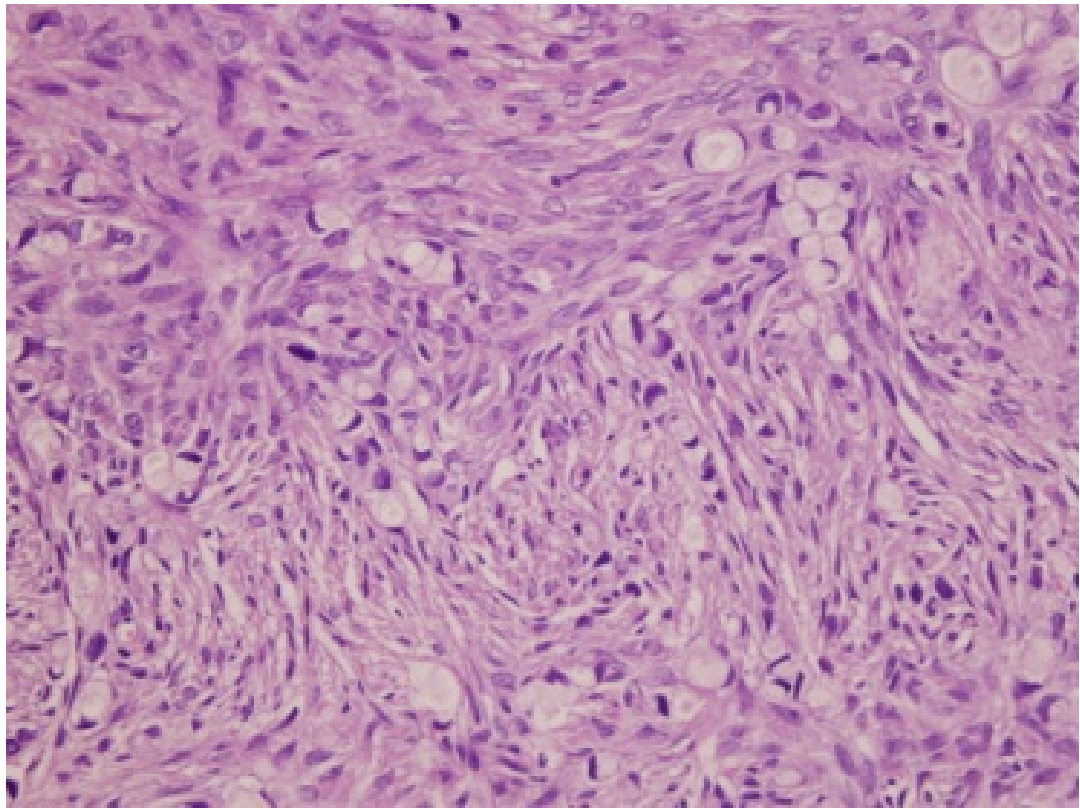

Figure 2: Breast tissue histology

\section{CASE PRESENTATION}

A 32-year-old married lactating woman, mother of 3 children presented to breast clinic with a rapid painless diffuse swelling of right breast over few weeks, not associated with redness, she had also mild diffuse abdominal pain but good appetite no vomiting no weight loss or change in bowel habit. Her review of systems was otherwise negative, no family history of cancer.

At breast clinic ultrasound and mammography of breast was taken the ultrasound of right breast revealed large size, hard, moderately heterogeneous tissue texture, multiple well defined hypo-echoic cystic lesions, largest one is $14 * 9 \mathrm{~mm}$ at 10 o'clock with multiple duct dilatation and periductal thickening. In right axilla inflammatory lymph node of $13 * 5 \mathrm{~mm}$ was detected, cortex of 3mm, echogenic hilum was detected, normal left breast and left axilla.

Mammography CC and MLO view was taken, breast composition ACR 4, a single superficial well defined dense lesion at superior-lateral aspect was seen, normal left breast, clear both axillae (Figure 1). Core biopsy from the mass was taken, histopathology reported metastatic mucin secreting adenocarcinoma (Figure 2). IHC was as follow ( ER negative, PR negative, HER2 negative, KI 67: 60\%, E-cadherin positive, CA125 negative, WT1 negative, mammaglobin negative, CDX2 positive, moderate nuclear staining (Figure 3 ). 


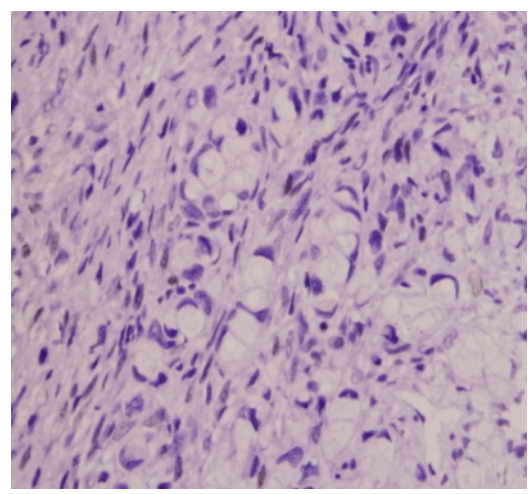

ER

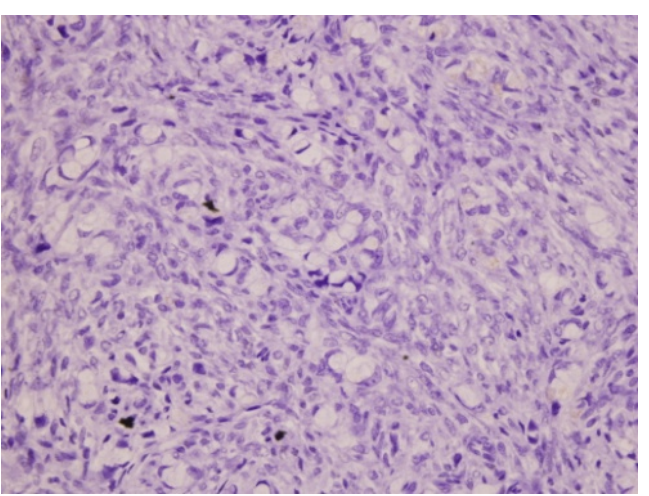

$\mathrm{PR}$

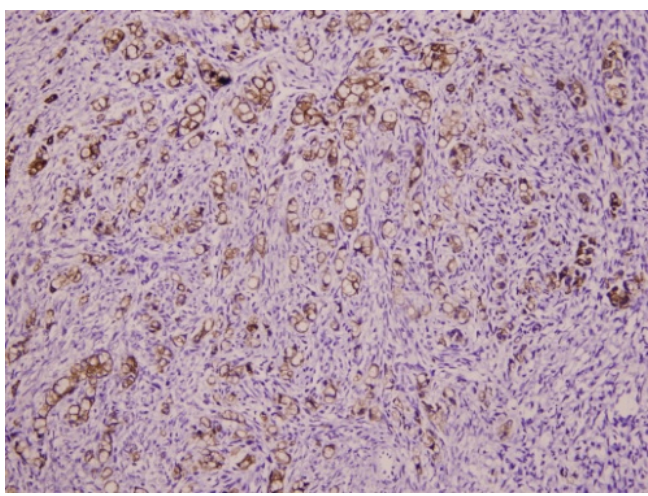

CK

Figure 3: Breast tissue histology

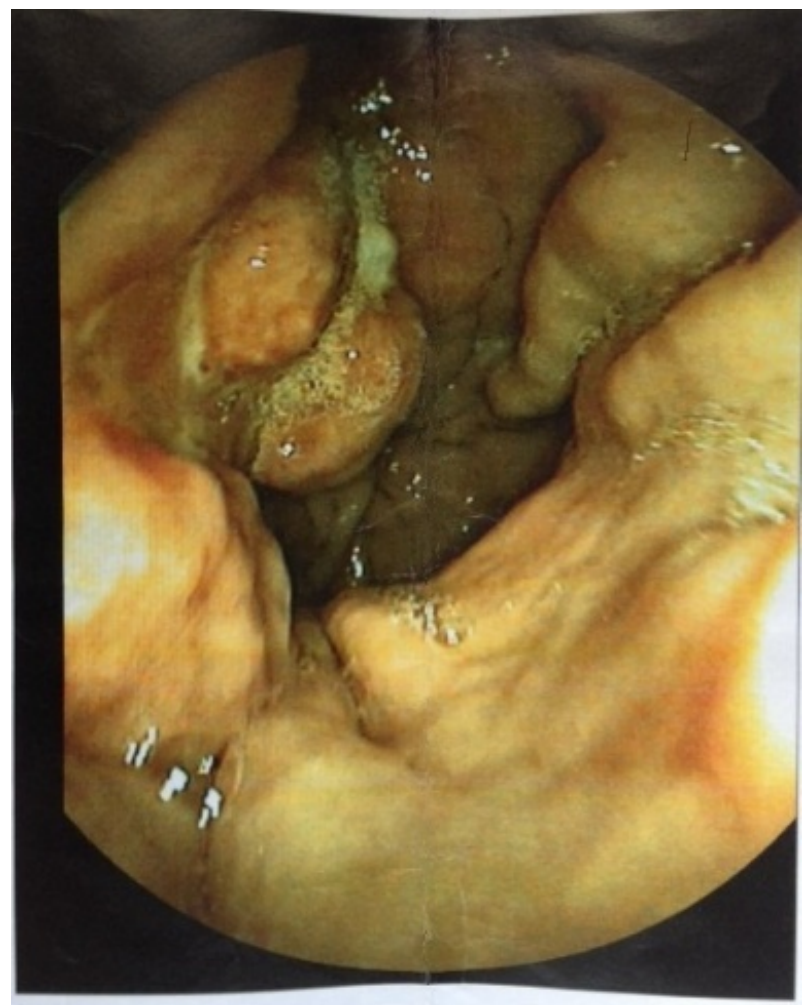

Figure 4: Gastric endoscopy

Abdominal and pelvis ascites, diffuse infiltration of the peritoneum with omental cake as well as stranding of pelvic fat, enlarged and enhanced right and left ovary, diffuse gastric wall thickening were visualized on Dynamic staging computed tomography (CT)scan of chest, abdomen and pelvis.

Tumor markers were as follows CEA: $1.2 \mathrm{ng} / \mathrm{ml}$, AFP: $2.23 \mathrm{lu} / \mathrm{ml}$, CA 19.9: $0.62 \mathrm{u} / \mathrm{ml}$, CA 125: $62.6 \mathrm{u} / \mathrm{ml}$, CA 15.3: 19.7 $\mathrm{u} / \mathrm{ml}$.

Gastroenteroscopy was performed, easily bleeding ulcers was seen over great curvature from mid body till antrum (Figure 4), histopathology of gastric lesion reported poorly differentiated adenocarcinoma diffuse signet ring type (Figure 5), IHC results was positive for AE1/AE3 and negative HER2 status.

With collaboration of our oncologist, pathologist, radiologist we diagnosed and managed our case as signet ring cell gastric cancer, and she was started on EOX (EPIrubicin $50 \mathrm{mg} / \mathrm{m}^{2}$, OXALlplatin $130 \mathrm{mg} / \mathrm{m}^{2}$, Capecitabin $625 \mathrm{mg} / \mathrm{m}^{2}$, on fifth cycle there was progression on image study, and unfortunately we lost her after 2 weeks. 

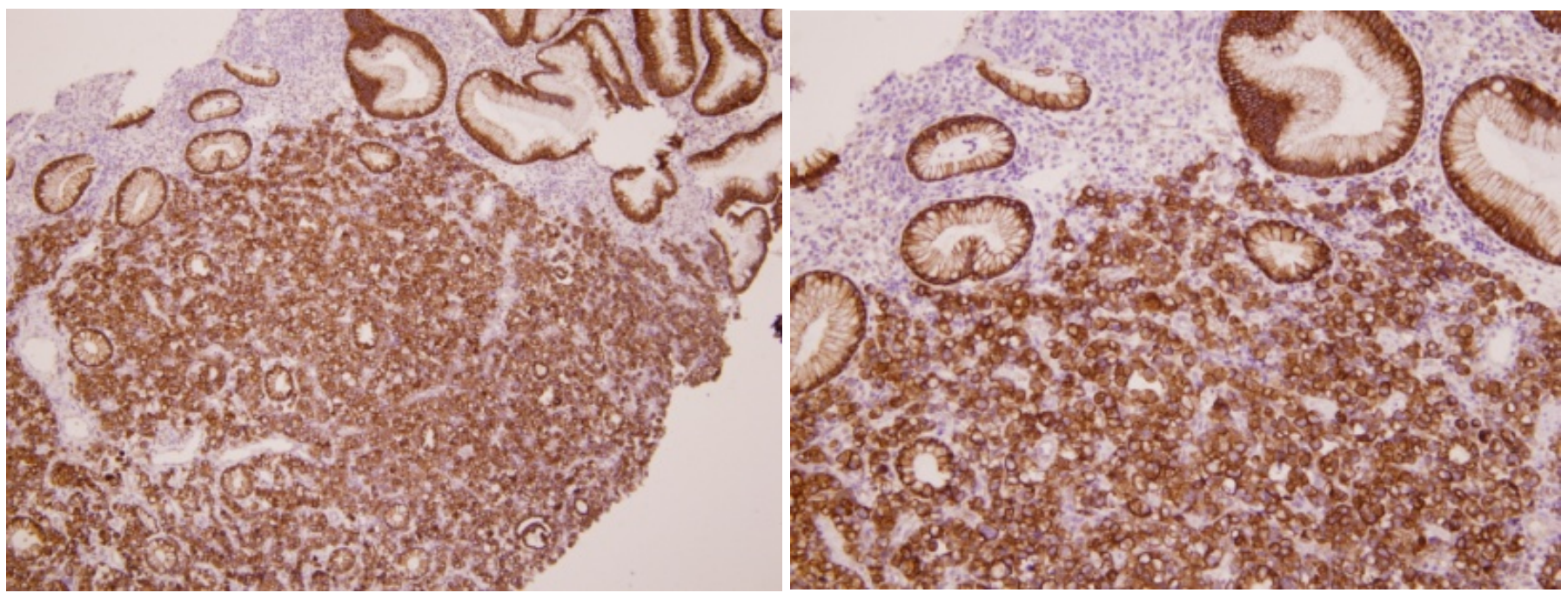

Figure 5: Histopathology of gastric tissue sample

\section{DISCUSSION}

Breast cancer accounts for the most common malignancies, but metastasis to breast from extra mammary malignancies is a rare condition and comprising around $3 \%$ of breast malignancies, the majority are from contralateral breast, less than $0.5 \%$ resulted from extra mammary sites (14). In $25 \%$ of cases breast involvement is bilateral (15).

Prognosis is poor, according to reported cases overall survival ranged from 12 day to 18 month (16).

Around 400 cases have been reported to have breast metastasis from extra-mammary sides, their incidence ranged from $1.7 \%-6.6 \%, 1.2 \%-2 \%, 2.7 \%$ in (autopsy, clinical, and cytological reports) (17), and the most common source from highest to lowest rate were from melanoma, lung, ovary, prostate, kidney, stomach, ileum, thyroid, cervix, squamous cell carcinoma of the tongue and floor of the mouth, fibrosarcoma of the nasal septum and pancreatic adenocarcinoma.

With our case another 38 case have been reported so far to have metastatic disease from stomach, 22 of them had histological feature of signet ring cell carcinoma (16).

Unlike our case that had synchronous multiple metastasis at presentation, breast metastases appears on the average 1.9 - 2.0 years after discovery of the primary lesion $(12,13,18)$, and usually signifies disseminated metastatic gastric tumor $(15,19)$, while in some cases there may be no history of neoplasm (14). The age at diagnosis ranges from 22-70 years (mean 46 years; median 46.5 years) $(16,20,21)$. Breast metastasis from gastric carcinoma mainly occurs in female $(95 \%)$ than male (5\%), Georgiannos et al. (14) attributed the reason behind this phenomena to differences in size and vascuarity between two gender's breast, hormonal factors, endothelial cell adhesion molecule, angiogenic factors, immunologic determinants, hormone receptor, or other cellular components also may play a role since they are expressed differently in male and female breast.

Secondary involvement of breast occurs mainly in elderly patients while lung and gastric cancer particularly signet ring cell variant of stomach develop in younger age group and anticipate more aggressive nature $(22,23)$.

Clinical manifestations are quite similar to primary breast cancer which make suspicion of elsewhere primaries unusual but essential to avoid; unnecessary radical operation and providing optimal treatment, reported cases in literatures had different presentation, from inflammatory breast cancer $(18,24,25)$ to painful/painless lumps and often occur in upper outer quadrant with presence of axillary lymphadenopathy $(12,13)$.

Radiological findings are not specific which makes the diagnosis quit difficult, they may present as a solitary or multiple lesions, well demarcated or poorly marginated masses, diffuse hypoechoic lesions, diffuse involvement of skin or parenchyma or both $(12,20)$, and some time there is no any radiologic findings $(26,27)$. Kawak et al. reported that for those with clinical feature suggesting inflammatory breast carcinoma after confirmation of signet ring cell breast carcinomas has been made, metastatic signet ring carcinomas should be considered if there is no micro-calcification or masses on radiographic findings $(13,18)$. But metastasis from ovarian carcinoma may demonstrate microcalcification with psammoma bodies $(28,29)$.

Pathologically it's hard to differentiate between primary breast cancer and metastasis, breast cancer can have ambiguous histological feature that can be easily mistaken for extra mammary cancers. (14) Some histologic feature my help in recognizing secondary from primary like absence of elastosis which is found in primary and indicating a slow 
growth and rarely found in secondary tumors (30). A sharp transition at the border of the tumor my give clue for metastasis (31). Tumors in subcutaneous rather than parenchymal or breast tissue and absence of in situ component support extra mammary origin (14).

Tumor metastasize to breast by unexplained pathway, this intriguing situation have been attributed to estrogen and high blood supply of breast in premenopausal women $(32,33)$.

Unlike our case in most of the reported cases breast metastasis from gastric cancer has happened in left breast although there is no consistent explanation but Lee et al, (19) reported that this laterality may suggest presence of a lymphatic pathway or higher incidence of breast invasion from stomach via left supraclavicular lymph node.

With our case another 5 cases have been reported to have breast and ovarian metastasis, it is uncommon to have invasion of hormonal-dependant organs especially in premenopausal women (26).

Immunohistichemistry of breast metastasis from stomach are usually positive for CK7, CEA, and GATA3 but negative for GCDFP-15(gross cystic disease fluid protein-15), ER, PR, and CK20. $(34,35)$ What supported our case to have breast metastasis from gastric cancer was having positive CDX2, CK7 and negative CK20, ER, PR, CA125, WT1, Mammaglobin, HER2 status.

$\mathrm{IHC}$ can differentiate metastatic signet ring cell carcinoma from primary signet ring cell carcinoma of breast, the latter one is a variant of invasive lobular carcinoma of breast and account for $14 \%$ of breast cancer (36), its incidence is increasing among postmenopausal women and have aggressive nature with tendency for early metastasis to abdomen and GIT tract, on IHC they demonstrate positive ER, PR and GCDFP $(34,37)$.

\section{CONCLUSION}

Breast metastasis from extra-mammary sites is uncommon with poor prognosis; clinical presentation might be quit misleading to primary breast cancer. Confirmation through clinical presentation, clinical history, histopathology, Immunohistichemistry and radiological examinations is crucial to ensure the appropriate therapy and avoiding unnecessary surgical treatment.

\section{REFERENCES}

1. Ferlay J, Shin HR, Bray F. Estimate of worldwide burden of cancer in 2008: GOLOBOCAN 2008. International Journal of Cancer, 2010 December 15;127(12):2893-917. https://doi.org/10.1002/ijc.25516 PMid:21351269

2. Hyung WJ, Noh SH, Lee JH, et al. Early gastric carcinoma with signet ring cell histology. Cancer, 2002 January 1;94(1):78-83. https://doi.org/10.1002/cncr.10120 PMid:11815962

3. Maehara $Y$, Sakaguchi $Y$, Moriguchi S, et al. Signet ring cell carcinoma of the stomach. Cancer, 1992 April 1;67(7):1545-1650. https://doi.org/10.1002/1097-0142(19920401)69:7 <1645::AID-CNCR2820690702>3.0.CO;2$\mathrm{X}$

4. Charalampakis N, Nogueras Gonzalez GM, Elimova E, et al. The Proportion of Signet Ring Cell Component in Patients with Localized Gastric Adenocarcinoma Correlates with the Degree of Response to Pre-Operative Chemoradiation. Oncology, 2016;90:239-47. https://doi.org/10.1159/000443506 PMid:27046280 PMCid:PMC4870109

5. Henger U, Blank $S$, Weicha $C$, et al. Is Preoperative Chemotherapy Followed by Surgery the Appropriate Treatment for Signet Ring Cell Containing Adenocarcinomas of the Esophagogastric Junction and Stomach? Annals of Surgical Oncology, 2014 May;21(5):1739-48. https://doi.org/10.1245/s10434-013-3462-z PMid:24419755

6. DeVita V, Lawrence S, Rosenberg A. Devita, Hellman, and Rosenberg's cancer: principles \& practice of oncology. 10th ed. Vincent T. DeVita, TSLSAR, editor. Woltes Kluwer Health; 2015.

7. Lauren P. The two histological main types of gastric carcinoma: diffuse and so-called intestinal-type carcinoma. An Attempt at a Histo-Clinical Classification, 1965 September;16:150-4. https://doi.org/10.1111/apm.1965.64.1.31 PMid:14320675

8. Casciato D, Territo M. Manual of Clinical Oncology. 7th ed. Philadelphia: Wolters Kluwe; 2012.

9. Abrams H, Spiro R, Goldstein N. Metastasis in carcinoma. Analysis of 1000 autopsied case. Cancer, 1950;3(1):7485. https://doi.org/10.1002/1097-0142(1950)3:1<74::AID-CNCR2820030111>3.0.CO;2-7 
10. Otsuji $E$, Yamaguchi T, Sawai $K$, et al. Characterization of signet ring cell carcinoma of the stomach. Journal of Surgical Oncology, 1998 April;67(4):216-20. https://doi.org/10.1002/(SICI)1096-9098(199804)67:4<216::AID$\mathrm{JSO} 2>3.0 . \mathrm{CO} ; 2-\mathrm{B}$

11. Vergier $B$, Trojani $M$, De Mascarel I, et al. Metastases to the breast: Differential diagnosis from primary breast carcinoma. Journal of Surgical Oncology, 1991 October;48(2):119-6. https://doi.org/10.1002/jso.2930480208 PMid:1921396

12. Toombs BD, Kalisher L. Metastatic disease to the breast: clinical, pathologic, and radiographic features. American Journal of Roentgenology, 1977 October;129(4):673-6. https://doi.org/10.2214/ajr.129.4.673

13. McCrea ES, Johnston C, Haney PJ. Metastases to the breast. American Journal of Roentgenology, 1983;141(4):685-90. https://doi.org/10.2214/ajr.141.4.685 PMid:6604418

14. Georgiannos SN, Aleong JC, Goode AW, et al. Secondary neoplasms of the breast. A survey of the 20th century. Cancer, 2001 November 1;92(9):2259-66. https://doi.org/10.1002/1097-0142(20011101)92:9<2259::AIDCNCR1571>3.0.CO;2-O

15. Alexander HR, Turnbull AD, Rosen PP. Isolated breast metastases from gastrointestinal carcinomas: Report of two cases. Journal of Surgical Oncology, 1989 December;42(4):264-6. https://doi.org/10.1002/jso.2930420412 PMid:2556613

16. He $C L, C h e n ~ P, X i a ~ B L$, et al. Breast metastasis of gastric signet-ring cell carcinoma: a case report and literature review. World Journal of Surgical Oncology, 2015 March 29;13(1):125. https://doi.org/10.1186/s12957-015-05381 PMid:25890325 PMCid:PMC4386101

17. Alva S, Shetty-Alva N. An Update of Tumor Metastasis to the Breast Data. Arch Surg., 1999;134(4):450. https://doi.org/10.1001/archsurg.134.4.450 PMid:10199322

18. Kwak JY, Kim EK, Oh KK. Radiologic findings of metastatic signet ring cell carcinoma to the breast from stomach. Yonsei Medical Journal, 2000;41(5):669-72. https://doi.org/10.3349/ymj.2000.41.5.669 PMid:11079630

19. Lee SK, Kim WW, Kim SH, et al. Characteristics of metastasis in the breast from extramammary malignancies. Journal of Surgical Oncology, 2010 February 1;101(2):137-40. https://doi.org/10.1002/jso.21453 PMid:20082359

20. lesato $A$, Oba $T$, Ono $M$, et al. Breast metastases of gastric signet-ring cell carcinoma: a report of two cases and review of the literature. OncoTargets and Therapy, 2018 December 29;8:91-7.

21. Hajdu SI, Urban JA. Cancers metastatic to the breast. Cancer, 1972;29(6):1691-6. https://doi.org/10.1002/10970142(197206)29:6<1691::AID-CNCR2820290637>3.0.CO;2-4

22. Pemberton JH, Nagorney DM, Gilmore JC, et al. Bronchogenic Carcinoma in Patients Younger than 40 Years. Ann Thorac Surg., 1983 November;36(5):509-15. https://doi.org/10.1016/S0003-4975(10)60678-9

23. Grabiec J, Owen DA. Carcinoma of the stomach in young persons, 1985 July 15;56(2):388-96. https://doi.org/10.1002/1097-0142(19850715)56:2<388::AID-CNCR2820560231>3.0.CO;2-J

24. Çil $T$, Altıntaş $A$, Paşa $S$, et al. Gastric ring cell carcinoma metastasis to the breast: Two case reports. Turkish Journal of Cancer, 2009;39(2):62-5.

25. Briest $S$, Horn LC, Haupt R, et al. Metastasizing Signet Ring Cell Carcinoma of the Stomach—Mimicking Bilateral Inflammatory Breast Cancer. Gynicologic Oncology, 1999 September;74(3):491-4. https://doi.org/10.1006/gyno.1999.5478 PMid:10479517

26. Boutis AL, Andreadis C, Patakiouta F, et al. Gastric signet-ring adenocarcinoma presenting with breast metastasis. World Journal of Gastroenterology, 2006 May 14;12(18):2958-61. https://doi.org/10.3748/wjg.v12.i18.2958 PMid:16718828 PMCid:PMC4087820

27. Qureshi SS, Shrikhande SV, Tanuja S, et al. Breast metastases of gastric signet ring cell carcinoma: A differential diagnosis with primary breast signet ring cell carcinoma. J Postgrad Med., 2005;51(2):125-7.

28. Paulus DD, Libshitz HI. Metastasis to the breast. Radiol Clin North Am., 1982 September;20(3):561-8.

29. Raptis $S$, Kanbour $A l$, Dusenbery $D$, et al. Fine-needle aspiration cytology of metastatic ovarian carcinoma to the breast, 1996 July;15(1):1-6. https://doi.org/10.1002/(SICI)1097-0339(199607)15:1<1::AID-DC2>3.0.CO;2-N

30. Azzopardi JG. Problems in breast pathology. Major problems in pathology Philadelphia: WB Saunders; 1979.

31. Silverberg SG, Masood S. Principle and Practice of surgicalpathology and cytopathology. 3rd ed. Silverberg SG, editor. New York: Churchill Livingstone; 1996.

32. Vergier $B$, Trojani $M$, Mascarel ID, et al. Metastases to the breast: Differential diagnosis from primary breast carcinoma, 1991 October;48(2):112-6. https://doi.org/10.1002/jso.2930480208 PMid:1921396 
33. Howarth CB, Caces JN, Pratt CB. Breast metastases in children with rhabdomyosarcoma. Cancer, 1980 December 1;46(11):2520-4. https://doi.org/10.1002/1097-0142(19801201)46:11<2520::AID-CNCR2820461134>3.0.CO;2-H

34. Raju U, Ma C, Shaw A. Signet ring variant of lobular carcinoma of the breast: a clinicopathologic and immunohistochemical study. Europe PMC, 1993 September 1;6(5):516-20.

35. Tot $\mathrm{T}$. The role of cytokeratins 20 and 7 and estrogen receptor analysis in separation of metastatic lobular carcinoma of the breast and metastatic signet ring cell carcinoma of the gastrointestinal tract, 2000 January;106(8):467-72. https://doi.org/10.1034/j.1600-0463.2000.d01-84.x PMid:11028811

36. Martinez V, Azzopardi JG. Invasive lobular carcinoma of the breast: incidence and variants. Histopathology, 1979 November;3(6):467-88. https://doi.org/10.1111/j.1365-2559.1979.tb03029.x PMid:229072

37. Merino MJ, Livolsi VA. Signet Ring Carcinoma of the Female Breast: A Clinicopathologic Analysis of 24 Cases. Cancer, 1981 October 15;48(8):8030-7. https://doi.org/10.1002/1097-0142(19811015)48:8<1830::AIDCNCR2820480821>3.0.CO;2-H

38. Cavazzini G, Colpani F, Cantore $M$, et al. Breast metastasis from gastric signet ring cell carcinoma, mimicking inflammatory carcinoma. Europe PMC, 1993 December;79(6):450-3. https://doi.org/10.1177/030089169307900617 PMid:8171750

39. An Update of Tumor Metastasis to the Breast Data. Arch Surg., 1999 April;134(4):450. https://doi.org/10.1001/archsurg.134.4.450 PMid:10199322

$$
\diamond \diamond \diamond \diamond \diamond \diamond \diamond
$$

http://www.ejgm.co.uk 